\title{
When IS A CODE A Code?
}

\section{ANDREW HEMming*}

This paper will develop the proposition that criminal codes in Australia are misnamed because they fail the fundamental test for a code of comprehensively stating the criminal law in one statute. This contention applies to all codes from the Griffith Codes of Queensland, Western Australia, Tasmania and the Northern Territory to the more recently minted Criminal Code 1995 (Cth). The reason for such failure is that all the codes are too sparsely written, and, due to inadequate definitional detail or statement of the appropriate tests to be applied, judges are required to have recourse to the common law to 'fill in the blanks' left by the code. It is here argued that a code needs to be structured with the objective of keeping statutory interpretation within the four corners of the code. Bland injunctions that recourse to the common law is permissible only when the meaning is uncertain or where a prior technical meaning existed are wholly inadequate.

The paper sets out a series of examples which cover both offences and defences (such as causation and provocation) and which are intended to demonstrate the appropriate level of detail required to meet the conventional definition of a true code without sacrificing clarity. These examples should be viewed as templates for use in a variety of contexts, supporting the proposition that clarity, not confusion, can result from more detailed drafting. Drafting of this kind, which is directed at incorporating the relevant tests that the legislature accepts as appropriate, reduces reliance on secondary material such as second reading speeches. Secondly, it firmly tilts the legislature-judiciary 'partnership' in favour of the legislature (as a true code should) leaving the judiciary to explain the tests to the jury rather than to select which tests are appropriate. In this way at least consistency within a code, rather than uniformity across codes, can be promoted.

\section{The MEANING Of A CODE}

In a map of the law executed upon such a plan there are no terrae incognitae, no blank spaces: nothing is at least omitted, nothing unprovided for: the vast and hitherto shapeless expanse of jurisprudence is collected and

\footnotetext{
* Lecturer in Law, Charles Darwin University.
} 
condensed into a compact sphere which the eye at the moment's warning can traverse in all imaginable directions. ${ }^{1}$

This paper endorses the above quotation from the pen of Jeremy Bentham, of whom the then Federal Minister for Justice, in the Second Reading Speech introducing the legislation that became the Criminal Code Act 1995 (Cth), said: 'codification of the criminal law has its roots in the work of the $18^{\text {th }}$ century jurist Jeremy Bentham'.2 In particular, this paper focuses on the words 'no blank spaces' which reflected Bentham's dislike of judge-made law because it was unwritten, uncertain and retrospective. ${ }^{3}$ It is here contended that the Criminal Code 1899 (Qld), the Criminal Code 1902 (WA) the Criminal Code 1924 (Tas) and the Criminal Code 1983 (NT) (the Griffith Codes) ${ }^{4}$ fail Bentham's test for a code ('no terrae incognitae') and that even Chapter 2 of the Criminal Code 1995 (Cth) does not pass muster.

Codification has been defined as 'the setting out in one statute of all the law affecting a particular topic whether it is to be found in statutes or in common law'. ${ }^{5}$ This aspirational view was certainly shared by Sir Samuel Griffith who 'envisaged that the Code should be a collected and explicit statement of the criminal law in a form that could be ascertained by an intelligent person', whilst pointing out to the Attorney-General in his famous Explanatory Letter that the criminal law of Queensland was scattered throughout nearly 250 statutes outside of the applicable common law. ${ }^{7}$

\footnotetext{
${ }^{1}$ H L A Hart (ed), Jeremy Bentham, Of Laws in General (Athlone Press, 1970) 246.

${ }^{2}$ Commonwealth, Parliamentary Debates, House of Representatives, 1 March 1995, 1,331 (Duncan Kerr, Minister for Justice).

${ }^{3}$ Bentham likened the common law to the way a man makes law for his dog by breaking a habit through a beating immediately after the event, since 'the dog only learns after the punishment that what it has done is wrong'. See Alan Norrie, Crime, Reason and History: A Critical Introduction to Criminal Law (Cambridge University Press, $2^{\text {nd }}$ ed, 2001) 19.

${ }^{4}$ While the Northern Territory has imported Chapter 2 of the Criminal Code 1995 (Cth) as Part IIAA effective from 20 December 2006, this presently applies only to a very narrow range of offences against the person listed in Schedule 1.

${ }^{5}$ Mr Justice Ronan Keane, 'Thirty Years of Law Reform 1975 - 2005', (Speech delivered at the $30^{\text {th }}$ Anniversary of the Law Reform Commission of Ireland, Farmleigh House, Phoenix Park, Dublin, 23 June 2005, 9.

${ }^{6}$ Simon Bronitt and Bernadette McSherry, Principles of Criminal Law (LBC, 2005) 72, citing Sir Samuel Griffith, 'Explanatory Letter to the Attorney-General Queensland with Draft Code' in K Whitney, M Flynn and P Moyle, The Criminal Codes (2000) 5.

${ }^{7}$ Sir Samuel Griffith, Explanatory Letter to Draft of a Code of Criminal Law (1897) iv. Another former Chief Justice of the High Court has stated that Griffith 'intended his Code to be an exhaustive statement of the law, and not merely a consolidation of part of it [but] the decisions that would interpret the Code would mean that the Code was not an exclusive source of law': Sir Harry Gibbs, 'The Queensland Criminal Code: From Italy to Zanzibar'
} 
The arguments for and against codification have been usefully collected by Farmer. ${ }^{8}$ The objections to codification are: (1) that 'the common law is uncodifiable'; (2) that such a code would 'sacrifice the flexibility of the common law, trapping its reasoning within rigid conceptual confines'; (3) that judge-made law is better or less out of touch than law made by the legislator; and (4) that the common law's greatest strength is its adaptability. This hostility to a code has been described as 'codiphobia', ${ }^{9}$ defined as a morbid fear and steadfast resistance to the ideas of codification emanating from the European continent. ${ }^{10}$

Mr Justice John Hedigan of the High Court of Ireland has addressed Farmer's four objections in favouring codification. ${ }^{11}$ The first objection to codification - that the common law is uncodifiable - would seem, according to Hedigan, to be countered by the experience of common law jurisdictions, such as Canada, ${ }^{12}$ the United States, ${ }^{13}$ New Zealand ${ }^{14}$ and Australia, that have adopted criminal codes. ${ }^{15}$ As regards Australia, it is significant in the context

(Speech delivered at the Opening of Exhibition at Queensland Supreme Court Library, Brisbane, 19 July 2002, 11.

${ }^{8}$ Lindsay Farmer, 'Reconstructing the English Codification Debate: The Criminal Law Commissioners, 1833-45' (2000) 18(2) Law and History Review 397, 398. Farmer here summarises the debate over the pros and cons of codification as follows: 'The code, in short, offers system, the common law adaptability - whatever the supposed merits of each.'

${ }^{9}$ Farmer, ibid, states that 'the term was coined by Andrew Amos, Professor of Law at University College, London, and a former law commissioner, to describe the failure of the English legislator to grasp the nettle of codification', citing Andrew Amos, Ruins of Time, exemplified in Sir Matthew Hale's Pleas of the Crown (Stevens and Norton, 1859), xvii.

${ }^{10}$ Peter Goodrich, Reading the Law: A Critical Introduction to Legal Method and Technique (Basil Blackwell, 1986) 24. Farmer argues that because codification was scarcely thought to merit study by those imbued with English common law principles, the conceptual tools to understand 'codification and legislation as part of the common law tradition, are simply not available': above n 8.

${ }^{11}$ Mr Justice John Hedigan, 'Codification of the Criminal Law and the European Convention on Human Rights' (2008) <http://www.isrcl.org/Papers/2008/Hedigan.pdf> 8-10, paper submitted at the 22nd International Conference of the International Society for the Reform of Criminal Law held in Dublin, Ireland from 11 July - 15 July, 2008.

${ }^{12}$ Criminal Code of Canada (1892). Canada has the reverse constitutional situation to Australia as regards the criminal law. 'The constitutional arrangement in Australia is that the general criminal law is a matter for the States and Territories and not for the Commonwealth': Matthew Goode, 'Constructing Criminal Law Reform and the Model Criminal Code' (2002) 26 Criminal Law Journal 152, 152.

${ }^{13}$ See, for example, the American Law Institute’s Model Penal Code promulgated in 1962 and which has influenced the fifty-two criminal codes in the United States.

${ }^{14}$ A Criminal Code Act was first introduced in New Zealand in 1893 and the current Crimes Act 1961 is a later enactment.

${ }^{15}$ Hedigan, above n $11,8$. 
of the common law's 'steadfast resistance, ${ }^{16}$ to continental codes that Sir Samuel Griffith derived 'very great assistance ${ }^{17}$ from Zanardelli's Italian penal code of $1888 .^{18}$ O’Regan has pointed out that the Griffith provisions are 'in materially the same terms' in Papua New Guinea. ${ }^{19}$

The second objection - that codification sacrifices the flexibility of the common law - overlooks, according to Hedigan, the need in any code for a degree of judicial interpretation in applying the code to situations that were not foreseen by the drafters of the code. ${ }^{20}$ Goode has suggested that a 'Code should provide better guidance for judges confronting a new situation'. ${ }^{21}$ Supreme and District Court Benchbooks ${ }^{22}$ already assist judges in delivering model directions to juries in standard cases (the directions often being based on appellate court decisions) and these Benchbooks could be expanded to cover almost every conceivable scenario.

The third objection - that judge-made law is superior to that of the legislator - rather depends on the uniform quality of judges and on how adequately the legislation has been scrutinised. In addition, 'beauty [in things] exists merely in the mind which contemplates them'. ${ }^{23}$ In this context, Goode has memorably described Thomas J's attack on the general principles outlined in the Model Criminal Code as 'mere unreasoned abuse'. ${ }^{24}$ In any event, the Criminal Code (Cth) and Part 2 in particular, could scarcely have gone through greater public scrutiny, starting with the Gibbs Committee, then the

\footnotetext{
${ }^{16}$ See above $\mathrm{n} 8$.

${ }^{17}$ Griffith, above n 7, vii.

${ }^{18}$ See Justice K A Cullinane, 'The Zanardelli Code and Codification in the Countries of the Common Law’ (2000) 7 James Cook University Law Review 116.

${ }^{19}$ Robin O’Regan, New Essays on Australian Criminal Codes (LBC, 1988) 2.

${ }^{20}$ Hedigan, above $n$ 11, 8.

21 Matthew Goode, 'Codification of the Australian Criminal Law' (1992) 16 Criminal Law Journal 5, 13.

22 See, eg, Department of Justice and Attorney-General, Supreme and District Court Benchbook (Queensland: The Department of Justice and Attorney-General, 2008).

23 David Hume, Essays, Moral and Political (Kincaid, 1741) Essay 23. See also Hedigan, above n 11, 9 .

${ }^{24}$ See above n 12, 159.
} 
long drawn out MCCOC process $^{25}$ and finally the emergence of the legislation itself, eclipsing any standard Law Reform Commission reference. ${ }^{26}$

The fourth objection addressed by Hedigan — regarding the superior adaptability of the common law as compared with a code - could equally be applied to the benefit of code interpretation, given judicial experience in adapting the common law to the circumstances of the case. ${ }^{27}$ Goode has pointed out that 'codification does not mean that every case must be specifically dealt with. The interpretative role of the judiciary will remain a vital element in the process. ${ }^{28}$ Farmer argues that the negative perception of codification as an interloper in the legal systemhas resulted in 'the existence of a long native tradition of codification [being] lost to view'. ${ }^{29}$

The arguments in favour of codification are, in Hedigan's view, (1) that 'a code enjoys democratic legitimacy’; ${ }^{30}$ (2) the law of the legislator is better than judge-made law as it provides 'a theory of adjudication binding judges to the code'; ${ }^{31}$ (3) 'codification offers accessibility where the common law is only accessible to those trained in the artificial reasoning of the law'; ${ }^{32}$ and (4) that the code 'offers system in the sense that it is both a restraint and a guide

${ }^{25}$ In 1991 the Standing Committee of Attorneys-General established the Model Criminal Code Officers' Committee (MCCOC) 'to prepare a uniform criminal code for all Australian jurisdictions ... [and the] MCCOC has since gone on to produce a further seven reports on various areas of Commonwealth criminal law': Stephen Odgers, Principles of Federal Criminal Law (LBC, 2007) 22 [0.0.140].

${ }^{26}$ A typical government reference to a Law Reform Commission covers a single issue and is reported on within 18 months.

${ }^{27}$ See Hedigan, above n 11, 9.

${ }^{28}$ Goode, above n 21, 12.

${ }^{29}$ See above n 8, citing Barbara Shapiro, 'Codification of the Laws in Seventeenth-Century England' [1974] Wisconsin Law Review 428, 428-31.

${ }^{30}$ Hedigan, above $\mathrm{n} 11,9$. The Law Commission of England and Wales observed that 'since the criminal law is arguably the most direct expression of the relationship between a State and its citizens, it is right as a matter of constitutional principle that the relationship should be clearly stated in a criminal code the terms of which have been deliberated upon by a democratically elected legislature': Law Commission of England and Wales, A Criminal Code for England and Wales Vol 2, Report No 177 (1989) [2.2]. Underlying codification is the democratic concept of res nullius that the law belongs to no one in particular. Expert Group on the Codification of the Criminal Law, Codifying the Criminal Law, Department of Justice, Dublin, Ireland (2004) [1.28].

${ }^{31}$ Hedigan, above n 11, 9 quoting the Expert Group on the Codification of the Criminal Law, 'Codifying the Criminal Law', Department of Justice, Dublin, Ireland (2004) [1.27]. The architect of the American Law Institute's Model Penal Code has argued that a code underlines the point that 'when so much is at stake for the community and the individual, care has to be taken to make law as rational and as just as law can be': Herbert Wechsler, 'The Challenge of a Model Penal Code' (1986) Criminal Law Review 285, 289-90. See Hedigan at 10.

${ }^{32}$ Hedigan, above n 11, 9 
to judges'. 33 In sum, one academic commentator has concluded that the 'central virtues' of codification are

readability, accessibility, simplicity and clarity ... if the code is effectively to articulate and announce the criminal law's rules of conduct. ${ }^{34}$

Taking up the last two virtues identified above - of simplicity and clarity can it be fairly said that a code which contains far greater detail still retains clarity and avoids becoming submerged in a mire of statutory interpretation? Firstly, comparisons between common law jurisdictions and code jurisdictions in Australia are muddied because lawyers in both jurisdictions commonly refer to 'multiple pieces of legislation'. ${ }^{35}$ Statutory interpretation is becoming ever more important ${ }^{36}$ and is complicated by the 'piecemeal nature' of criminal legislation. A comprehensive 'catalogue of offences' and defences goes some way to aiding both the transparency and understanding of the criminal law. ${ }^{37}$

Secondly, it is recognised that the limitations and ambiguity of language will constrain the goal of keeping interpretation of the code's terms within the four corners of a code. Also, the changing nature of social values, the creativity of advocates and the ingenuity of criminals all ensure that a code cannot be a closed system. Nevertheless, if a code starts from the proposition of 'covering the field' with the intention of distilling the relevant law through the specific selection or rejection of available legal options and tests, the room for manoeuvre within the code is reduced. Then all the well known rules of statutory interpretation, such as the rule that a provision be read in context ${ }^{38}$ or that a construction that promotes the purpose ${ }^{39}$ underlying the code shall be preferred, come to the fore. This paper is not a search for a perfect and

\footnotetext{
${ }^{33}$ Ibid, citing Expert Group, above n 31, [1.27].

${ }^{34}$ Paul Robinson, Structure and Function in Criminal Law (Oxford University Press, 1997) 183 as quoted by Hedigan, ibid 10 .

${ }^{35}$ See Griffith, above n 7. See also n 21, 10, where Goode gives a list of common law offences in force in South Australia in the general area of offences of a public nature: 'This, mind you, is just a list of the offences - discovering their content and coverage is yet another step.'

${ }^{36}$ For example, in Campbell v R [2008] NSWCCA 214 (16 September 2008) the appeal turned on the meaning of the word 'imports', and in $R v$ Toe [2010] SASC 39 the appeal rested on the physical element of 'importing'. Campbell was construed in the context of s 307.11 and Toe under s 307.2 of the Criminal Code 1995 (Cth).

${ }^{37}$ For the quotations in this paragraph see Hedigan, above n 11, 10 and his quotation from $\mathrm{Mr}$ Justice Peter Charleton, 'Homicide: Murder and Manslaughter', Conference Paper at the Law Reform Commission Launch of their Report on Homicide, Dublin, 29 January 2008, 5-6.

${ }^{38}$ K \& S Lake City Freighters Pty Ltd v Gordon and Gotch Ltd (1985) 157 CLR 309, 315 (Mason J).

${ }^{39}$ See, eg, Acts Interpretation Act 1901 (Cth) s 15AA.
} 
complete code, but an attempt to demonstrate that codes can be far truer to their intended design than is commonly thought.

So how has the concept of codification translated into the Australian context? Gani has differentiated between (a) codification as per the Griffith Codes or the Model Criminal Code, which the learned author defines as a 'complete statement of the $\operatorname{law}^{40}$ on the particular issue with which it deals', ${ }^{41}$ and (b) codification of an 'area of law within the context of a larger statute', ${ }^{42}$ for instance by'covering the field on a discrete subject' ${ }^{43}$ as exemplified by the law of self-defence within the Crimes Act 1900 (NSW).

This paper takes issue with any criminal code in Australia being described as approaching a complete statement of the criminal law, and Gani herself points out that the Model Criminal Code Officers Committee (MCCOC) failed to spell out their concept of codification in any of their reports. Gani observes that the MCCOC's 'treatment of the codification chapter of the M[odel] C[riminal] C[ode] [Chapter 1] is extraordinarily brief (effectively, one page) and does not directly engage with conceptual issues or comparative perspectives'. 44

Instead, the MCCOC was content to tacitly endorse, via supporting footnotes, the views of two writers: MCCOC member Matthew Goode ${ }^{45}$ and English academic Andrew Ashworth. ${ }^{46}$ Goode's definition of a criminal code is enlightening and provides a useful test against which to measure the success of any criminal code.

[A Criminal Code is a] pre-emptive, systematic, and comprehensive enactment of the whole field of law. It is pre-emptive in that it displaces all other law and its subject areas save only that which the Code excepts. It is

40 Citing here Dennis Pearce and Robert Geddes, Statutory Interpretation in Australia (Butterworths, $5^{\text {th }}$ ed, 2001) [8.7] and [1.20].

41 Miriam Gani, 'Codifying the Criminal Law: Implications for Interpretation' (2005) 29 Criminal Law Journal 264, 267.

42 Ibid.

43 Ibid.

44 Ibid 268. The precursor to the MCCOC, the Gibbs Committee, adopted a conservative approach to criminal law reform: 'It should be noted that codification does not necessarily involve radical reform; the Review Committee would not propose to depart widely from existing principles, but would rather propose generally to restate existing principles whilst at the same time to fill gaps, remove obscurities and correct anomalies': Review of Commonwealth Criminal Law, Interim Report: Principles of Criminal Responsibility and Other Matters (AGPS, 1990) 14 (Emphasis added).

${ }^{45}$ Goode, above $n 21$.

${ }^{46}$ Andrew Ashworth, 'Interpreting Criminal Statutes: A Crisis of Legality?' (1991) 107 Law Quarterly Review 419. 
systematic in that all of its parts, arranged in an orderly fashion and stated with a consistent terminology, form an interlocking, integrated body, revealing its own plan and containing its own methodology. It is comprehensive in that it is sufficiently inclusive and independent to enable it to be administered in accordance with its own basic policies. ${ }^{47}$

By 'comprehensive' Goode 'does not mean that a Criminal Code can or should be absolutely comprehensive [but] should take in all major indictable and summary offences'. ${ }^{48}$ Goode's concern is to point out that a line has to be drawn somewhere, which he sees as a policy decision, and his discussion centres on whether juvenile offences, proceeds of crime legislation or pollution offences et al should be part of a criminal code. This paper respectfully agrees that such a pragmatic, broad-brush policy delineation is necessary. However, the real issue is the nature of the concept 'comprehensive' in relation to all major indictable offences and of course the available defences.

Goode's justification of codification of the criminal law in Australia is grounded on 'four very basic principles of social justice" ${ }^{49}$ which he identifies as easy to find, easy to understand, cheap to buy, and democratically made and amended. This echoes Ashworth's expectation of a criminal code that it be

an authoritative statement of the major offences [which under a code] would be more accessible and more comprehensible, and there would be greater consistency in terminology and greater certainty in the scope of offences. ${ }^{50}$

As Gani has noted, the language used by Goode and Ashworth above 'is highly reminiscent of that used by Sir Samuel Griffith' ${ }^{51}$ in his 1897 explanatory letter to the then Attorney-General of Queensland, ${ }^{52}$ which leads Gani to conclude that 'the principles underlying the Model Criminal Code are very similar to those underlying the Griffith Codes of the $19^{\text {th }}$ century' ${ }^{53}$ But the codification of principles of social justice are a far cry from the codification of general principles of criminal law. The Model Criminal Code

\footnotetext{
${ }^{47}$ Above n 21, 9, citing W D Hawkland, ‘Uniform Commercial Code Methodology’ [1962] University of Illinois Law Forum 291-2 quoted in Letourneau and Cohen, 'Codification and Law Reform: Some Lessons from the Canadian Experience’ (1989) 10 Statute Law Review 183, 183.

${ }^{48}$ Goode, above n 21, 9.

${ }^{49}$ Ibid 8.

${ }^{50}$ Ashworth, above n 46, 420.

${ }^{51}$ Gani, above n 41, 269.

52 Above $n 7$.

${ }^{53}$ Above n 41, 269.
} 
is a clear improvement on the Griffith Codes which are caught in a $19^{\text {th }}$ century time warp, perhaps requiring Doctor Who and the TARDIS (Time And Relative Dimension(s) In Space) to transport Sir Samuel Griffith into the $21^{\text {st }}$ century if there is to be any prospect of Queensland accepting the Model Criminal Code.

\section{INTERPRETATION OF CRIMINAL CODES}

The enactment and operation of Criminal Codes in Australia for over a century has inevitably required the High Court to consider on numerous occasions the appropriate principles to be applied to code interpretation. Pearce and Geddes have suggested that the main issue that has required the attention of the courts is the extent to which regard may be had to the common law or previous statutes in interpreting a criminal code. ${ }^{54}$ Kirby $\mathrm{J}$ has addressed this issue in several judgments ${ }^{55}$ but the most succinct version is to be found in Charlie $v$.

Although a code is enacted by legislation and thus attracts the general rules applicable to the task of statutory construction, it is a special type of legislation. It does not (unless expressly stated) set out to be a mere restatement of the pre-existing or common law. [Boughey $v$ The Queen (1986) 161 CLR 10, 30 (Brennan J)]. It is not uncommon for codes, including in the area of criminal law, to introduce fundamental changes. [ $R$ v Martyr [1962] Qd R 398, 413 (Philp J)] Accordingly, it is erroneous to approach the meaning of a code with the presumption that Parliament's purpose was to do no more than restate the pre-existing law. [Brennan $v$ The King (1936) 55 CLR 253, 263 (Dixon and Evatt JJ).] The first loyalty, as it has been often put, is to the code. [ $R v$ Jervis [1993] 1 Qd R 643, 647 (McPherson ACJ); $R \vee$ Barlow (1997) 188 CLR 1, 32 (Kirby J)] Where there is ambiguity, and especially in matters of basic principle, the construction which achieves consistency in the interpretation of like language in similar codes of other Australian jurisdictions will ordinarily be favoured. [Zecevic v Director of Public Prosecutions (Vict) (1987) 162 CLR 645, 665 (Wilson, Dawson and Toohey JJ).] But before deciding that there is ambiguity, the code in question must be read as a whole. [cf $R v$ Jervis [1993] 1 Qd R 643, 652 (McPherson ACJ)]. The operation of a contested provision of a code, or any other legislation, cannot be elucidated by confining attention to that provision. It must be presumed that the objective of the legislature was to give an integrated operation to all of the provisions of the code taken as a whole, and an effective operation to provisions of

\footnotetext{
${ }^{54}$ Pearce and Geddes, above n 40, [8.8].

${ }^{55}$ See, eg, $R$ v Barlow (1997) 188 CLR 1 and Murray $v$ The Queen (2002) 211 CLR 193.
} 
apparently general application, except to the extent that they are expressly confined or necessarily excluded. ${ }^{56}$

The above passage is helpful as far as it goes. References to the fact that first loyalty should be to the code and thatthe code should be read as a whole are familiar tenets of statutory construction and could equally well be applied to the Australian Constitution, which is the very epicentre of Australian law. The Australian Constitution is a very sparsely written document and the High Court has wrestled with its interpretation since Federation. This paper contends that Criminal Codes in Australia suffer from the same defect, are too sparsely written and perforce require the judiciary to develop the law around the substantive sections.

This in turn raises two related questions, one of which goes to policy and the other to technical meaning. Firstly, to what extent is the use of such sparse language a deliberate policy decision by the legislature to engage in 'powersharing' with the judiciary, notwithstanding the fact that a code is supposed to be a comprehensive enactment? Secondly, to what extent is the general part of the code - encompassing the principles of criminal responsibility - either irrelevant or inadequate for the purpose of construing the application of substantive offences?

Given that one of the reasons for having a code is to confine judicial lawmaking, it is, as Gani suggests, 'ironic that the development of the rules governing the interpretation of criminal and other codes in Australia has fallen and continues to fall largely within the province of the judiciary' ${ }^{57}$ So can any clear guidance be had from Chapter 1 of the Criminal Code (Cth) regarding the construction of the Code? Leader-Elliott drily observes that 'Chapter 1 of the Code is stark in its brevity, a solitary provision declaring that the only offences against laws of the Commonwealth are those created by Commonwealth statute', ${ }^{58}$ while Gani notes that the 'MCCOC shied away from the issue'. 59

There may have been good reason for adopting such a small-target approach, given the hostile reception of the original interpretation section of the Draft Criminal Code put forward by the Law Commission of England and Wales. ${ }^{60}$

\footnotetext{
${ }^{56}$ [1999] 199 CLR 387, 394 [14] (footnotes in quoted material summarised in insertions).

${ }^{57}$ Gani, above n 41, 273.

${ }^{58}$ Ian Leader-Elliott, 'Elements of Liability in the Commonwealth Criminal Code' (2002) 26 Criminal Law Journal 28, 31.

${ }^{59}$ Gani, above n 41, 273.

${ }^{60}$ Law Commission of England and Wales, A Criminal Code for England and Wales Vol 1, Report No 177 (1989) [3.14]-[3.15].
} 
Essentially, the argument against the inclusion of a construction clause was that 'it was felt that provisions on interpretation were unnecessary insofar as they restate general principles of construction ${ }^{61}$ or, in the alternative, 'it was unwise to attempt to draft a comprehensive set of provisions [because] they would unbalance the Code and produce their own difficulties of interpretation'. ${ }^{62}$ One wonders if this attack was from a 'fifth column' ${ }^{63}$ of common law diehards seeking to minimise the reach of code provisions.

In any event, for present purposes, it is illuminating to juxtapose LeaderElliott's comment that Chapter 2 of the Criminal Code (Cth) 'is based on article 2 of the American Penal Code and the equivalent general part of the UK Draft Criminal Code ${ }^{64}$ with Gani's observation that the drafting team of the Draft Criminal Code accepted arguments that the provision [on interpretation] was 'unnecessary [and] potentially dangerous' ${ }^{65}$ because it 'directs attention to the previous law and seems to invite a search for ambiguity ${ }^{66}$ [such that] the construction and illustration provisions were omitted from the Draft Code Bill. ${ }^{67}$

All that can be gleaned from the singular failure of the MCCOC to address the important issue of construction is that 'it appears that the principles enunciated by the High Court, and particularly Kirby J, will apply to the interpretation of Criminal Codes in Australia' ${ }^{68}$

This paper therefore answers the first question above by concluding that the paucity of language in Chapter 1 of the Criminal Code (Cth) demonstrates a clear policy decision by the legislature to engage in 'power-sharing' with the judiciary, with the MCCOC content to leave windows into the Code through which the common law freely passes. As will be demonstrated in later sections, the common law is implicitly incorporated into all the Criminal Codes of Australia both by reference and by design.

Turning now to the second question above, one must ask: how successful is a general part in construing the application of substantive offences? A useful

\footnotetext{
${ }^{61}$ Ibid [3.15].

${ }^{62}$ Ibid.

${ }^{63}$ A fifth column is a group of people who clandestinely undermine a larger group from within to benefit an external enemy.

${ }^{64}$ Ian Leader-Elliott, 'Benthamite Reflections on Codification of the General Principles of Criminal Law: Towards the Panopticon’ (2006) 9(2) Buffalo Criminal Law Review 391, 391.

${ }^{65}$ Law Commission, above n 60, [3.21].

${ }^{66}$ Ibid.

${ }^{67}$ Gani, above n 41, 274 citing Law Commission of England and Wales, above n 60, [3.24].

${ }^{68}$ Gani, above n 41, 275.
} 
starting point can be found in Dixon CJ's well known criticism of section 13(1) of the Criminal Code (Tas) in Vallance $v R^{69}$ Leader-Elliott has suggested that Dixon CJ's analysis of the Tasmanian incarnation of section 23 of the Griffith Queensland Code and his Honour's attack on section 13(1), the central provision of criminal responsibility in the Criminal Code (Tas), 'was to have a devastating effect on attempts to articulate a coherent theory of criminal liability in jurisdictions which adopted the Griffith Code'. ${ }^{70}$

Vallance was charged with unlawful wounding. The question the High Court had to determine was the relationship between the offence of unlawful wounding and section 13(1) Criminal Code (Tas) which was derived from section 23 Criminal Code (Qld) and expressed in the following terms.

No person shall be criminally responsible for an act unless it is voluntary and intentional; nor ... for an event which occurs by chance.

Dixon CJ fired his first salvo at Sir Samuel Griffith by declaring that

an examination of the Code, in an attempt to answer what might have been supposed one of the simplest problems of the criminal law [the place of intention on a charge of unlawful wounding], leaves no doubt that little help can be found in any natural process of legal reasoning. ${ }^{71}$

Dixon CJ continued in similar vein by deriding the introductory part of the Code for containing 'wide abstract statements of principle about criminal responsibility framed rather to satisfy the analytical conscience of an Austinian jurist than to tell a judge at a criminal trial what he ought to do'. ${ }^{72}$ By this Dixon CJ meant that such abstractions of doctrine were not to be interpreted as general deductions from specific instances that followed but came ' $a b$ extra and speak upon the footing that they will restrain the operation of what follows'. 73

The problem, as Dixon CJ explained, was that the plan of the Tasmanian Code was to provide for specific offences whilst at the same time treating their complete definition as finally determined by Chapter IV (criminal responsibility). Such a complete definition could not be uniformly undertaken because

\footnotetext{
69 (1961) 108 CLR 56.

${ }^{70}$ Leader-Elliott, above n 58, 29.

${ }^{71}$ Vallance v The Queen (1961) 108 CLR 56, 58.

${ }^{72}$ Vallance v The Queen (1961) 108 CLR 56, 58.

${ }^{73}$ Vallance v The Queen (1961) 108 CLR 56, 58.
} 
common sense rather suggests that guilt will depend on definitions that in point of fact will fall outside the philosophy of s 13 [and] to turn over the sections of the Code is enough to show how large a number of crimes there are to the elements of which s 13(1) can have little or nothing to say. ${ }^{74}$

Dixon CJ then applied s 13(1) — which he took to be saying that all the acts of the defendant that formed the elements of the offence had to be voluntary and intentional - to the offence of unlawful wounding and concluded that the wounding must be voluntary and intentional (not reckless).

This then led to Dixon CJ's second salvo at the architect of the Criminal Code (Qld), namely,

that it is only by specific solutions of particular difficulties raised by the precise facts of given cases that the operation of such provisions as s 13 can be worked out judicially. ${ }^{75}$

Such a trenchant statement can be likened to an Exocet missile directed at the very heart of a code's objective to be a complete statement of the law ('no blank spaces') and to minimise the need for judge-made law.

Leader-Elliott has suggested that Dixon CJ's argument was essentially that 's 13(1) was an unnecessary irrelevance'. ${ }^{76}$ This seems a little broad, but certainly accurate for the type of offences that Dixon CJ identified, such as fraud, personation, sexual offences, receiving et al. More telling is LeaderElliott's observation that Dixon CJ's judgment went to the central defect of the Griffith Codes, namely, 'their near complete failure to anticipate the effects which the general provisions of the Code were supposed to have on the analysis and application of the substantive offences'. ${ }^{77}$ Thus, the plan upon which the Code was conceived fell apart because the central criminal

\footnotetext{
${ }^{74}$ Vallance v The Queen (1961) 108 CLR 56, 60.

${ }^{75}$ Vallance $v$ The Queen (1961) 108 CLR 56, 61. Two good examples of provisions being worked out judicially can be seen in the interaction between s 31 of the Criminal Code (NT) and, firstly, the now repealed s 162(1)(a) of the same Act which dealt with murder, and, secondly, the now amended s 192 of the same Act which covers sexual assault. In the first example, in Charlie v The Queen ([1999] 199 CLR 387, 410 [69]) Callinan J held that the express reference to intent in s 162(1)(a) meant that s 31 of the Criminal Code (NT) had no role to play as all the mental elements were set out in s 162(1)(a). In the second example, in Director of Public Prosecutions (NT) v WJI [2004] 219 CLR 43, 48-49 [8], Gleeson CJ held that in relating ss 192(3) and 31(1) of the Criminal Code (NT), having regard to the definition of 'act' ('deed ... not limited to bodily movement'), a broad interpretation of 'act' necessarily followed such that the relevant act is having sexual intercourse with another person without the consent of the other person, as opposed to the DPP's contention that the 'act' was sexual intercourse itself.

${ }^{76}$ Leader-Elliott, above n 58, 30.

${ }^{77}$ Ibid.
} 
responsibility sections were either an optional extra or hopelessly intermingled with the substantive offence rather than governing the particular offence provision.

Leader-Elliott's description above of Dixon CJ's judgment as 'devastating' appears somewhat dramatic given that section 23 has survived unscathed and, some 20 years after Vallance was decided, the Northern Territory opted for a variation of the Griffith Code. However, a case can be made that the common law jurisdictions were likely to take some comfort that Australia's greatest judge was not enamoured of the Griffith Codes. Furthermore, the limitations of section 23(1)(b) of the Criminal Code (Qld) (which states that a person is not criminally responsible for an event that occurs by accident) ${ }^{78}$ in dealing with killings that have resulted from so called 'one-punch' assaults led the Queensland Government to refer the excuse of accident following widespread public disquiet to the Queensland Law Reform Commission. Somewhat surprisingly, the Commission recently recommended that section 23(1)(b) should be retained. ${ }^{79}$

The Commission was apparently unable to envisage any other alternative than the repeal of section 23(1)(b), pointing out that repeal would have far reaching consequences because 'accident' applies generally to criminal offences and not just to manslaughter. ${ }^{80}$ The Commission concluded that the excuse of accident was 'a critical provision of the Code' and therefore the 'Code should continue to include an excuse of accident'. ${ }^{81}$ Ironically, the solution to the issues that the Queensland Government referred to the Commission on the excuse of accident was readily available in the form of Part 2.2 of the Criminal Code (Cth) and the definitions of the fault elements for criminal responsibility contained therein.

Leader-Elliott has argued that the counterweight to Dixon CJ's criticisms can be found in the

seminal [judgment] delivered by Brennan J in He Kaw Teh $v$ The Queen ${ }^{82}$ [which] looks forward to Chapter 2 of the Model Criminal Code [and] provided the template for the provisions which set out the elements of criminal liability. ${ }^{83}$

\footnotetext{
${ }^{78}$ The equivalent section in the Criminal Code (WA) is s 23B(2).

${ }^{79}$ Queensland Law Reform Commission, A Review of the Excuse of Accident and the Defence of Provocation, Report No 64, (2008) 9.

${ }^{80}$ Ibid 184.

${ }^{81}$ Ibid 184-5.

82 (1985) 157 CLR 523.

${ }^{83}$ Leader-Elliott, above n 58, 29.
} 
The learned author goes on to liken Part 2.2 of the Criminal Code (Cth) which is based on the Model Criminal Code

to rules of statutory interpretation [which] possess a quasi-constitutional status because they articulate principles of common law which are generally taken to embody fundamental principles of criminal justice. ${ }^{84}$

In a more recent article, Leader-Elliott has stated that '[i]t is implicit in the Code that the general principles and the definitions of concepts in Chapter 2 take priority over the localised "context and subject matter" of particular offences ${ }^{85}$ by virtue of Part 2.2 ('Application') which states that Chapter 2 applies to all offences against this Code. The learned author unfavourably compares this with Griffith's Queensland Criminal Code where he describes the general principles as having been vitiated as a result of 'their subordination to the local particularities of the substantive offences'. ${ }^{86}$ Thus, the position put by Leader-Elliott is that Part 2.2 overcomes the problems with the Griffith Codes identified by Dixon CJ in Vallance, and by implication is both a substantial improvement on the Griffith Codes and meets Bentham's criterion of 'no blank spaces'.

The most important component of Chapter 2 of the Criminal Code (Cth) is Part 2.2, which covers the elements of an offence. The formula ${ }^{87}$ adopted is that an offence consists of physical and fault elements (although an offence may provide for no fault element in the case of strict or absolute liability). ${ }^{88}$ Physical elements can be conduct, a result of conduct or a circumstance in which conduct, or a result of conduct, happens. Fault elements can be

\footnotetext{
${ }^{84}$ Ibid 31.

${ }^{85}$ Ian Leader-Elliott, ‘The Australian Criminal Code: Time for Some Changes' (2009) 37(2) Federal Law Review 205, 210.

${ }^{86}$ Ibid.

${ }^{87}$ See Regina $v$ J S [2007] NSWCCA 38, (10 September 2004) [145] (Spigelman CJ): 'Fundamental aspects of the law have been altered by the Criminal Code in substantial and indeed critical matters, by the replacement of a body of nuanced case law, which never purported to be comprehensive, with the comparative rigidity of a set of interconnecting verbal formulae which do purport to be comprehensive and which involve the application of a series of cascading provisions, including definitional provisions, expressed in language intended to be capable of only one meaning, which meaning does not necessarily reflect ordinary usage.'

${ }^{88}$ See Regina v J S [2007] NSWCCA 38, (10 September 2004) [152] (Spigelman CJ): 'No provision of the Code states that a physical element which is a question of law for the judge cannot have attached to it a fault element which the jury must decide. The Code makes no direct distinction between questions of law and questions of fact. It does, however, make express provision for decoupling a specific physical element, relevantly a question of law, from any fault element. This can be done by either providing that no fault element applies to that physical element (under s 3.1(2)) or by specifying that strict or absolute liability applies to the offence (under s 6.1 or s 6.2 ).'
} 
intention, knowledge, recklessness or negligence, all of which are defined. For example, the definition of negligence in section 5.5 is based closely on Nydam $v$ The Queen. ${ }^{89}$

In $R v$ Saengsai-Or Bell $\mathrm{J}$ explained the operation of Chapter 2 in relation to an offence as follows:

An offence consists of physical and fault elements. Liability for the commission of an offence is dependent upon proof of each physical element of the offence together with proof of the fault element that is applicable to each physical element. An offence may comprise more than one physical element and different fault elements may apply to each physical element: s 3.1 (provision is made for the law creating an offence to specify that there is no fault element for one or more of the physical elements of the offence). In the absence of specification of the fault element (or specification that there is no fault element) for a physical element the Criminal Code makes provision for default fault elements: s 5.6.

Intention is the default fault element for a physical element that consists only of conduct: s 5.6(1). Recklessness is the default fault element for a physical element that consists of a circumstance or a result: s 5.6(2). ${ }^{90}$

Essentially, the basic offence structure (physical and fault elements) of the Criminal Code (Cth) is that the conduct (act) must be intentional and the person engaging in the conduct must be reckless (the threshold for liability) either as to the result of the conduct or as to the circumstance in which the conduct happens. Leader-Elliott has rightly described recklessness as the 'ubiquitous fault element' ${ }^{91}$ which requires an awareness of a substantial risk, the taking of which is unjustifiable. The subjective requirement of 'awareness' for recklessness is the sole distinction between recklessness and negligence in the Criminal Code (Cth). (The test for the latter is totally objective, negligence requiring such a great falling short of the standard of care that a reasonable person would exercise, and such a high risk that the physical element exists, that the conduct merits criminal punishment.) Notwithstanding the fact that Part 2.2 treats the distinction between recklessness and negligence as fundamental (only recklessness contains a subjective component), it was demonstrated in Simpson $v$ The Queen that there is a thin line between recklessness and negligence - between the actual (subjective) awareness of a risk and the objective awareness of the risk based

\footnotetext{
${ }^{89}$ [1977] VR 430.

${ }^{90} R v$ Narongchai Saengsai-Or [2004] NSWCCA 108 (19 August 2004) [42]-[43].

${ }^{91}$ Leader-Elliott, above n 58, 39.
} 
on the fact that the risk was obvious. ${ }^{92}$ It requires but a small step to envisage that the 'fall back' fault element of recklessness in the Criminal Code (Cth) may not be up to the task it has been allocated, as Leader-Elliott has acknowledged. $^{93}$

In $R v$ Saengsai-Or, the appellant appealed against his conviction under section 233B(1)(b) Customs Act 1901 (Cth) for importing into Australia a trafficable quantity of heroin concealed in two bottles of brandy. Bell $\mathrm{J}$ considered that the physical element of the offence created by section 233B(1)(b) was one of conduct: the act of importing into Australia any prohibited import to which the section applies. Her Honour found that in respect of this physical element, which consists only of conduct, the provisions of $\mathrm{s} 5.6(1)$ of the Criminal Code apply. Intention is the fault element'. ${ }^{94}$ The jury members at first instance had been directed that if they were satisfied of the appellant's awareness of a substantial risk that the brandy bottles contained narcotics and that in the circumstances it was unjustifiable to take that risk, then the element of intention would be proved. As the jury had thus been directed on recklessness, Bell J held that this was a misdirection. ${ }^{95}$

More recently, the High Court in The Queen $v$ Tang $^{96}$ was required to consider an appeal by the Crown against the quashing of convictions under section 270.3(1)(a) Criminal Code (Cth), which dealt with possession of a slave or the exercise over a slave of any of the other powers attaching to the right of ownership. The Court of Appeal of the Supreme Court of Victoria had quashed Ms Tang's convictions, holding that the jury should have been instructed that the prosecution had to prove that Ms Tang had the knowledge or belief that the powers being exercised were obtained through ownership, as well as proving the intention of Ms Tang to exercise those powers. The prosecution had appealed to the High Court.

\footnotetext{
92 (1998) 103 A Crim R 19. In Simpson, the High Court was construing s 157(1)(c) of the Criminal Code 1924 (Tas) which deals with murder and, in particular, whether the offender knew or ought to have known whether the unlawful act was likely to cause death in the circumstances. The High Court held that if a fact or circumstance is so well known that no reasonable person in the community would dispute it (here stabbing the deceased in the general area of the upper body), a jury may safely infer that the offender (appellant) knew it unless denial by him raises a reasonable doubt about his knowledge.

${ }^{93}$ Leader-Elliott, above n 58, 39-40. Ian Leader-Elliott makes the point that in England, following Caldwell v Commissioner of Police ([1982] AC 341), 'the distinction between recklessness and negligence notoriously collapsed', going on to suggest that the difficulties of maintaining the distinction across a range of offences 'are considerable' as are 'the temptations to dilute the requirement of actual awareness'.

${ }^{94} R v$ Narongchai Saengsai-Or [2004] NSWCCA 108 (19 August 2004) [72].

${ }^{95} R v$ Narongchai Saengsai-Or [2004] NSWCCA 108 (19 August 2004) [75].

${ }^{96}$ [2008] HCA 39 (28 August 2008).
} 
The High Court allowed the appeal, holding that the prosecution had made out the required elements of the offences and did not need to prove what Ms Tang knew or believed about her rights of ownership. The prosecution did not need to prove that she knew or believed that the women were slaves. The critical powers that she exercised were the power to make each woman an object of purchase, the capacity to use the women in a substantially unrestricted manner for the duration of their contracts, the power to control and restrict their movements, and the power to use their services without commensurate compensation. ${ }^{97}$

Gleeson CJ took issue with the reasoning of the Court of Appeal in the following terms:

Chapter 2 of the Code does not provide support for the Court of Appeal's reasoning ... [T] $[\mathrm{T}$ he physical element of the offence was conduct, which is defined to include both an act and a state of affairs ... Both possessing a slave and using a slave are conduct, and the prosecution had to establish the existence of the conduct and one of the fault elements specified in s 5.1(1). The prosecution case was conducted on the basis that the relevant fault element was intention ... Eames JA said that all of sub-ss (1), (2) and (3) of s 5.2 were relevant. This is not easy to understand: sub-s (1) applies where the physical element is conduct; sub-s (2) applies where the physical element is a circumstance; sub-s (3) applies where the physical element is a result. Section 4.1 says a physical element may be conduct or a result of conduct or a circumstance in which conduct or a result of conduct occurs.

The physical element was conduct (which includes a state of affairs); the fault element was intention. It was, therefore, s 5.2(1) that was relevant. A person has intention with respect to conduct if he or she means to engage in that conduct. Knowledge or belief is often relevant to intention. If, for example, it is the existence of a state of affairs that gives an act its criminal character, then proof of knowledge of that state of affairs ordinarily will be the best method of proving that an accused meant to engage in the proscribed conduct. ${ }^{98}$

Two conclusions can be drawn from $R v$ Saengsai-Or and The Queen $v$ Wei Tang. The first is that judges have the same difficulties in interpreting Chapter 2 of the Criminal Code (Cth) as any other code or statute. Secondly, Dixon CJ's dicta in Vallance that specific solutions to code provisions have to be worked out judicially are as valid today as when the then Chief Justice wrote them in 1961. Leader-Elliott rather optimistically considers that Chapter 2 has

\footnotetext{
${ }^{97}$ Public Information Officer, High Court of Australia, 'The Queen v Wei Tang' (Media Release, 28 August 2008).

98 The Queen v Tang [2008] HCA 39 (28 August 2008) [46]-[47] (emphasis in original) (citations omitted).
} 
'emerged unscathed, indeed reinforced, as a consequence of judicial scrutiny by the High Court in $R v$ Tang ... remarkable for the strict literalism of its interpretation of Part 2.2'.99

In $R \vee J S,^{100}$ Spigelman CJ gave an extended analysis of the statutory interpretation of Chapter 2 of the Criminal Code (Cth). In that case, the court was concerned with the intentional destruction of data that might later be required in judicial proceedings, contrary to section 39 of the Crimes Act 1914 (Cth). Spigelman CJ drew attention to the need for the elements of section 39 to be interpreted within the context of the relevant Criminal Code (Cth) provisions 'which require a particular analysis, in accordance with the requirements of that Code' ${ }^{101}$ For example, His Honour pointed out that '[b]y reason of the express reference to knowledge in s 39 of the Crimes Act 1914 (Cth), the relevant fault element for present purposes is "knowledge" which is defined in s 5.3' [Criminal Code (Cth)]. ${ }^{102}$ In this respect, the Criminal Code (Cth) with its specific matching of physical and fault elements seeks to avoid the criticisms that Dixon CJ in Vallance levelled at the Griffith Code in general and section 13 of the Criminal Code (Tas) in particular. An important aspect of the case was that Spigelman CJ rejected the appellant's submission that there were categories of fault elements that arose by implication despite being unspecified in the provisions of the Code.

In its submissions to this Court the Appellant sought to draw a distinction between different kinds of elements of an offence. It invoked a distinction between 'substantive' and 'definitional' characteristics of a physical element of an offence, suggested by the author of a text on the Code. ${ }^{103}$ It also invoked a similar distinction, drawn by the author of another text, between 'facts' and 'statutory references or designations'. ${ }^{104}$

I do not think it is open, when construing a Code, to decide that there are elements of an offence that are merely 'definitional' or 'referential' in such manner as to permit the words used in the formulation of the offence to be set aside. The very breadth of the definition of 'physical element', encompassing as it does anything capable of answering the description of a

\footnotetext{
${ }^{99}$ Leader-Elliott, a above n 85, 205.

${ }^{100}$ Regina v J S [2007] NSWCCA 38 (10 September 2004).

${ }^{101}$ Regina v J S [2007] NSWCCA 38 (10 September 2004) [8]. Spigelman CJ stated that the relevant provisions of the Criminal Code (Cth) were s 3.1 ('Elements'); s 3.2 ('Establishing guilt in respect of offences'); s 4.1 which deals with matters capable of constituting a physical element (here, s 4.1(1)(c) - a circumstance in which conduct occurs); and sections 5.1 and 5.3 which cover the relevant fault element (here, knowledge): [8]-[11].

${ }^{102}$ Regina v J S [2007] NSWCCA 38 (10 September 2004) [11].

103 Odgers, above n 25, 22 [4.1.390].

${ }^{104}$ Commonwealth Attorney-General's Department, The Commonwealth Criminal Code: A Guide for Practitioners (2002) 119.
} 
'circumstance', indicates that all of the words of a statutory offence to which the Criminal Code applies must be given force and effect. ${ }^{105}$

Thus, there is support for the claim that judicial interpretation of Part 2.2 should be conducted with 'strict literalism', of which Dixon CJ would doubtless have approved. For example, in Campbell $v R$ Spigelman CJ held that the new statutory context of a code ${ }^{106}$ covering a wide range of drug offences suggested 'that a precise, rather than expansive, sense of the word "imports" 107 has been adopted'. ${ }^{108}$ However, the more important question is whether the approach to Criminal Code (Cth) interpretation 'on the basis it comprehensively states each of the elements of a criminal offence, ${ }^{, 109}$ is sound. Spigelman CJ states that such an approach follows of necessity because '[t]hat is the central purpose of adopting a Code'. ${ }^{110}$ However, his Honour goes on to point out that there is a built-in assumption to this approach, namely, that:

[I]t is apparent on the face of the offence, as interpreted in the light of the Criminal Code precisely what are the physical elements of an offence and to precisely which of those physical elements a fault element, if any, attaches and what that fault element is. ${ }^{111}$

This of greater significance, bearing in mind that the principles of criminal responsibility in Chapter 2 were born out of a Code seeking to address the

\footnotetext{
${ }^{105}$ Regina v J S [2007] NSWCCA 38 (10 September 2004) [126]-[127].

${ }^{106}$ Spigelman CJ notes that 'the Commonwealth's long standing legislative regime with respect to imports was engrafted upon the proposed national model for drug offences': Regina $v \mathrm{~J} S$ [2007] NSWCCA 38 (10 September 2004) [114]. His Honour continues by quoting from the Explanatory Memorandum for the Bill which explains that the import and export offences in Division 307 are based on the Customs Act 1901 (Cth) whereas the other offences are based on Chapter 6 of the Model Criminal Code which was developed in 1998 by the MCCOC. [115].

${ }^{107}$ Section 300.2 of the Criminal Code (Cth) now contains a definition of the word 'import' in order to overcome the decision in Campbell $v R$.

108 [2008] NSWCCA 214 (16 September 2008) [126]. In Campbell the jury was handed a document identifying six elements of which they had to be satisfied beyond reasonable doubt in order to convict the appellant. The most important element was number 5: that Mrs Campbell knew that there were tablets with pseudoephedrine in them inside container DLCU 2141810 or Mrs Campbell was aware of a substantial risk that there were tablets with pseudoephedrine in them inside container DLCU 2141810 and, in the circumstances known to her, it was unjustifiable for her to take that risk by importing the container.

${ }^{109}$ Regina v J S [2007] NSWCCA 38 (10 September 2004) [129] (Spigelman CJ).

${ }^{110}$ Regina v J S [2007] NSWCCA 38 (10 September 2004) [129] (Spigelman CJ).

${ }^{111}$ Regina v J S [2007] NSWCCA 38 (10 September 2004) [129] (Spigelman CJ).
} 
interpretation of offences against the person which, as Leader-Elliott acknowledges, 'are of only marginal importance in federal jurisdiction' ${ }^{112}$

In Crowther v Sala, ${ }^{113}$ a case where the relevant fault element was disputed, the applicant appealed her conviction under section 474.17(1) of the Criminal Code (Cth), which deals with using a carriage service (here a telephone line) to menace, harass or cause offence. There was no dispute as to the relevant content of the applicant's two telephone calls made 10 minutes apart, which was to the effect that unless she got an answer to her question she would get a shotgun and was going to use it on everyone in the complainant's office. The Magistrate rejected the applicant's contention that she was only using Australian colloquialisms in finding that, objectively, a reasonable person would find her words menacing. On appeal, the District Court judge agreed in applying an objective test.

The Queensland Court of Appeal divided 2:1 on a further appeal by the applicant. Williams JA dissented, finding that the only fault element necessary for the offence was the intention to use the telephone and utter the words. He considered that, because section 474.17(1)(b) contained the phrase 'that reasonable persons would regard as being in all the circumstances, menacing', the subjective intent of the person uttering the words was not relevant. ${ }^{114}$ His Honour concluded that 'a fault element has been excluded by necessary implication with respect to the element of the offence that reasonable persons would in the circumstances regard the conduct in question as menacing'. ${ }^{115}$

The judgment for the majority was given by Philip McMurdo $\mathrm{J}$ who found that there was no implied exclusion of the fault element in section 474.17(1)(b) and that what must be proved is 'that objectively viewed the conduct was menacing and that the defendant either intended that it be so or was reckless as to that fact'. ${ }^{116}$ His Honour reached that conclusion by virtue of section 5.6(2), which provides that, if the law creating the offence does not specify a fault element for a physical element that consists of a circumstance or a result, then the corresponding fault element is recklessness. As the Magistrate had made no finding as to what the applicant had thought about her conduct at the time, the appeal was allowed.

Interestingly, Leader-Elliott has viewed the decision in Crowther $v$ Sala as something of a double-edged sword. On the one hand, the learned author

\footnotetext{
${ }^{112}$ Leader-Elliott, above n 58, 31.

${ }^{113}$ [2007] QCA 133 (20 April 2007).

${ }^{114}$ Crowther v Sala [2007] QCA 133 (20 April 2007) [23]-[25].

${ }^{115}$ Crowther v Sala [2007] QCA 133 (20 April 2007) [27].

${ }^{116}$ Crowther v Sala [2007] QCA 133 (20 April 2007) [47].
} 
applauded the decision as 'a salutary instance of strict construction of the requirements of Chapter $2^{, 117}$ whilst also finding that the decision represented 'a danger signal, requiring legislative intervention'. ${ }^{118}$ Leader-Elliott's preferred amendment to the Code would be 'to the effect that falling short of an OP [ordinary person] or RP [reasonable person] standard constitutes a Division 5 fault element'. ${ }^{119}$ This fault element would operate in a similar manner to the existing fault element of negligence and thereby avoid the automatic application of section 5.6 ('Offences that do not specify fault elements') 'when breach of the standard is characterised as a circumstantial element of an offence'. ${ }^{120}$

This is a novel suggestion and entirely consistent with the architecture of Chapter 2 with its interconnecting formulae. ${ }^{121}$ However, as the case law on the Criminal Code (Cth) grows, it can be confidently anticipated that judges will be increasingly required to decide as to which physical and fault elements apply to specified offences under the circumstances of the particular case. Such an outcome would be unsurprising given both the formulaic nature of Part 2.2 and the breadth of Commonwealth offences. ${ }^{122}$ So perhaps the Criminal Code (Cth) has not so much emerged 'unscathed' or 'reinforced' as it has started to undego a period of judicial clarification natural for a code which was first minted in 1995 and which marks a major break with the architecture of the Griffith Codes.

One area that may require judicial clarification is that of causation, which is an element of an offence against the person. In contrast with the Criminal Code (Cth), the Griffith Codes give considerable attention to causation. For example, the general causation provision in the Criminal Code (Qld) is

\footnotetext{
${ }^{117}$ Leader-Elliott, above n 85, 230.

${ }^{118}$ Ibid.

${ }^{119}$ Ibid 232.

${ }^{120}$ Ibid.

${ }^{121}$ John Gardner has identified a distinction between the definitional general part, which Leader-Elliott suggests corresponds to Chapter 2, and the supervisory general part which Leader-Elliott suggests corresponds to the Commonwealth Attorney-General's Department Guide to Framing Commonwealth Offences, Civil Penalties and Enforcement Powers (2007). See above n 85, 215-6, citing John Gardner, 'On the General Part of the Criminal Law: Principles and Critique' in R A Duff (ed), Philosophy and the Criminal Law (Cambridge University Press, 1998) 208-9.

${ }^{122}$ See, eg, the Crimes Legislation Amendment (Serious and Organised Crime) Act 2010 (Cth) which amended the following Commonwealth Acts: Crimes Act 1914, Criminal Code Act 1995, Customs Act 1901, Family Law Act 1975, Proceeds of Crime Act 2002 and the Telecommunications (Interception and Access) Act 1979. One of the amendments to the Criminal Code Act 1995 was to insert a new s 11.2A ('Joint Commission') into Part 2 which incorporates the notion of joint criminal enterprise.
} 
section $293^{123}$ which is then extended by the terms of sections 294 to $298^{124}$ which have the effect of deeming the defendant to have caused death in particular circumstances. However, the test for causation is not defined in the Griffith Codes, and judges have had recourse to decided cases. The leading case is Royall $v R^{125}$ where the High Court identified four basic tests for causation: the operating and substantial cause test; the natural consequences test; the reasonable foresight of consequences test; and the novus actus interviens test. $^{126}$

The only Australian Criminal Code to nominate one of these tests of causation is the Criminal Code (NT) where in section 149C the operating and substantial cause test has been singled out. ${ }^{127}$ Lamentably, the Criminal Code (Cth) has ignored the question of causation altogether. Thus, for sections 115.1 to 115.4 , which respectively cover murder, manslaughter, intentionally causing serious harm and recklessly causing serious harm, the courts will have to decide which test of causation is applicable in the circumstances of the case when it must be decided whether the chain of causation has been broken. Kenny has suggested that for the Griffith Codes of Queensland and Western Australia the 'test is whether the accused's actions were a substantial or significant cause of death', ${ }^{128}$ arguing that, if the test of foreseeability is adopted, 'there is little or no scope for the operation of the excuse of accident [s 23] under the Codes'. ${ }^{129}$ However, the respective State legislatures remain silent on this matter, presumably preferring the flexibility of the common law.

\footnotetext{
${ }^{123}$ Section 293 states: 'Except as hereinafter set forth, any person who causes the death of another, directly or indirectly, by any means whatever, is deemed to have killed that other person.' The equivalent section in the Criminal Code (WA) is s 270.

${ }^{124}$ The equivalent sections in the Criminal Code (WA) are ss 271-5.

125 (1991) 172 CLR 378.

${ }^{126}$ Royall v R (1990) 172 CLR 378, 449 (Brennan J).

${ }^{127}$ Section 149C ('Causing death or harm') states: 'For an offence under this Part [Part VI ('Offences against the person and other matters')], a person's conduct causes death or harm if it substantially contributes to the death or harm.' The implication from this single sentence is that the court is to apply Hallett $v R$ [1969] SASR 141 which was approved by the two judges in Royall (Toohey and Gaudron JJ) who endorsed the operating and substantial cause test.

${ }^{128}$ R G Kenny, An Introduction to Criminal Law in Queensland and Western Australia (LexisNexis Butterworths, $7^{\text {th }}$ ed, 2008) 239 [12.19].

${ }^{129}$ Ibid. Under s 23 an accused is not criminally responsible for an event which is unforeseen by him and not reasonably foreseeable. Kenny cites $R v$ Jemielita (1996) 81 A Crim R 409 where the appellant appealed his murder conviction on the grounds that the evidence did not allow the sequence of the injection and ingestion of drugs to be established beyond reasonable doubt, and therefore the deceased's own conduct may have constituted an intervening act.
} 
The author has contended elsewhere ${ }^{130}$ that even the specific nomination of one of the general tests of causation identified in Royall is not sufficient if the more detailed common law tests are to be encoded or excluded. The author set down the following extended version of section 149C as a template for a code seeking to cover the field and to leave 'no blank spaces'. It is designed to fully reflect the common law under the rubric or heading of the 'substantially contributes' test of causation and to utilise the deeming provisions of the Griffith Codes.

Section 149C. Causing death or harm

(1) For an offence under this Part, a person's conduct causes death or harm if it substantially contributes to the death or harm.

(2) For the purpose of this section, conduct includes direct or indirect means, threats, intimidation or deceit.

(3) For the purpose of this section, substantially means more than trivial or minimal but need not be the sole cause or even the main cause of the victim's death.

(4) For the purpose of this section, a novus actus interveniens must be voluntary in the sense that the intervening act is free, deliberate and informed, and later conduct can only constitute a novus actus interveniens if it was not itself caused by the earlier conduct. The test to be applied is that the later conduct must be so independent of the accused's acts, and in itself so potent in causing death, that the contribution made by the accused is reduced to insignificance.

(5) For the purpose of this section, any person who causes to another person any harm from which death results, kills that person, although the immediate cause of death be treatment proper or improper, applied in good faith. $^{131}$

Notwithstanding the lack of attention to causation in the Criminal Code (Cth), arguably, Bentham's test of 'no blank spaces' in a Criminal Code may be met for the elements of an offence in Part 2.2, but can the same be said for defences and excuses? It is therefore now appropriate to turn to Part 2.3 which covers circumstances in which there is no criminal responsibility.

\footnotetext{
${ }^{130}$ Andrew Hemming, 'In Search of a Model Code Provision for Murder in Australia' (2010) 34(2) Criminal Law Journal 81, 85-7.

${ }^{131}$ Ibid 87.
} 


\section{Circumstances in Which There is No Criminal RESPONSIBILITY}

For a defendant to be found guilty of an offence, not only must fault be proved against the defendant but it must also be proved that no defences or excuses prima facie open on the evidence are available (for example, through the prosecution negativing self defence beyond reasonable doubt). In other words, the availability of defences must be disproved. Such a binary structure of criminal responsibility, which is the combination of proven fault liability with the elimination of any defence or excuse, 'is common to all modern codes derived from the common law' ${ }^{132}$ For example, Part II of the Criminal Code (NT) is entitled 'Criminal Responsibility' and is divided into four Divisions: ‘General Matters', 'Authorisation', 'Justification’ and 'Excuse'.

In the terminology of the Criminal Code (Cth), the offences are to be found in Part 2.2 and the defences in Part 2.3, which is entitled 'Circumstances in which there is no criminal responsibility' and sets out the defences that are generally available. Part 2.3 covers the field of available defences, some of which, such as self-defence (section 10.4), do not follow the common law. With the usual exception of mental impairment (section 7.3(3)), section 13.3(3) provides that 'a defendant who wishes to rely on any exception, exemption, excuse, qualification or justification provided by the law creating the offence bears the evidential burden [of establishing a 'reasonable possibility'] in relation to that matter'.

The available defences listed in Part 2.3 are: lack of capacity for criminal responsibility; mental impairment; intoxication; mistake or ignorance; intervening conduct or event; duress; sudden or extraordinary emergency; and self-defence. Significantly, while section 115.1(d) of the Criminal Code (Cth) covers murder of an Australian citizen or a resident of Australia outside Australia, following the recommendations of the MCCOC in the context of developing a uniform criminal code for Australian jurisdictions, there is no provision in Part 2.3 for either of the partial defences to murder, namely provocation and diminished responsibility. These two partial defences do exist in both the Criminal Code (Qld) and the Criminal Code (NT), and will be addressed in a later part of this section.

Of the available defences in Part 2.3, Division 9 covers 'Circumstances involving mistake or ignorance', and 9.5 deals with 'Claim of Right'. The MCCOC stated that "Claim of right" normally negatives a fault element, usually, but not necessarily, one of dishonesty, and the Code should reflect

${ }^{132}$ Leader-Elliott, above n 58, 32. 
that state of the law'. ${ }^{133}$ Section 9.5 has been singled out elsewhere by the present author as an example of inadequate drafting ${ }^{134}$ and will be used here to support the contention that brief sections that hide or imply a considerable body of case law are unsatisfactory and fail Bentham's 'no blank spaces' test.

Section 9.5 Criminal Code (Cth) currently reads as follows:

Claim of right

(1) A person is not criminally responsible for an offence that has a physical element relating to property if -

(a) at the time of the conduct constituting the offence, the person is under a mistaken belief about a proprietary or possessory right ; and

(b) the existence of that right would negate a fault element for any physical element of the offence.

(2) A person is not criminally responsible for any other offence arising necessarily out of the exercise of the proprietary or possessory right that the person mistakenly believes to exist.

(3) This section does not negate criminal responsibility for an offence relating to the use of force against a person.

The word 'property' is not defined in the existing section 9.5. The present author has argued $^{135}$ that the meaning of 'property' should be defined to narrow the scope of the defence and to explicitly amend existing common law authority ${ }^{136}$ as might be done through the proposed subsection below.

For the purposes of the definition of property in this section, property means a person's honest claim to some right in the property the subject of the charge that is personal to him or her. The honest claim of right must extend to the whole of the property taken, and does not include property taken in compensation as opposed to a right in relation to identified property.

133 Criminal Law Officers Committee of the Standing Committee of Attorney's General, Commonwealth Parliament, Model Criminal Code Chapter 2 - General Principles of Criminal Responsibility (1992) 61.

134 See Andrew Hemming, 'The Time Has Come to Tighten the Reach of Honest Claim of Right in Australian Criminal Codes’ (2008-9) 11 Newcastle Law Review 167.

135 Ibid 205.

${ }^{136}$ Walden $v$ Hensler (1987) 163 CLR 561. In the absence of any definition of property in s 9.5 , the broad definition of property taken by the majority of the High Court in Walden $v$ Hensler would perforce be 'imported' into s 9.5 rather than the proposed definition of property which reflects Pearce v Paskov (1968) WAR 66. 
Another of the present author's proposed amendments to section 9.5 reflects the powerful dissent of Wells $\mathrm{J}$ in $R v$ Lopatta, ${ }^{137}$ who was concerned at the reach of 'honest claim of right' at common law.

The honest claim of right must be of a kind that is, given favourable circumstances, recognised by Australia's system of law and an honest claim which in no circumstances would be recognised by Australia's system of law is excluded from this section. ${ }^{138}$

The thrust of the present author's earlier article was that the excuse of honest claim of right, which is limited to property, finds expression in all the Criminal Codes in Australia, ${ }^{139}$ and that, because all of the relevant sections are comparatively short, ${ }^{140}$ they rely on the common law to interpret the reach of the excuse, for example through applying the principles that the mistaken belief does not have to be reasonable provided that it is genuinely held; ${ }^{141}$ that the fact that the claim is wrongheaded does not matter; ${ }^{142}$ and that the claim may be unfounded in law or in fact. ${ }^{143}$ In $R v$ Fuge ${ }^{144}$ Wood CJ at CL identified a total of nine common law principles relating to an honest claim of right, all of which are implicitly imported into section 9.5 of the Criminal Code (Cth), but of which the lay reader is totally unaware. In this paper, the argument of? honest claim of right is extended to cover a variety of circumstances where, like an inexorable tide, the common law seeps into all corners of the Codes in Australia.

A further example from the list of defences in Part 2.3 of the Criminal Code (Cth), namely section 10.2 ('Duress'), ${ }^{145}$ will be annotated in the square brackets and footnotes below to illustrate the cases and interpretations that sit behind the section like invisible ink. There are strong similarities between the defence of duress and the defence of sudden or extraordinary emergency (necessity) in section 10.3. For example, both defences require that the person

\footnotetext{
137 (1983) 35 SASR 101, 103.

${ }^{138}$ Hemming, above n 134, 205.

${ }^{139}$ Criminal Code 1995 (Cth) s 9.5; Criminal Code 1983 (NT) s 30(2) and s 43AZ; Criminal Code 2002 (ACT) s 38; Criminal Code 1899 (Qld) s 22; Criminal Code 1902 (WA) s 22; and Criminal Code 1924 (Tas) ss 42, 44, 45, 226(1) and 267(3).

${ }^{140}$ For example, s 22(2) of the Criminal Code (Queensland) and the Criminal Code (WA) both simply state: 'But a person is not criminally responsible, as for an offence relating to property, for an act done or omitted to be done by the person with respect to any property in the exercise of an honest claim of right and without intention to defraud.'

${ }^{141} R v$ Pollard [1962] QWN 13.

${ }^{142} R \vee$ Gilson and Cohen [1944] 29 Cr App R 174.

${ }^{143} R v$ Bernhard [1938] 2 KB 264.

${ }^{144} R v$ Fuge [2001] NSWCCA 208 (4 June 2001) [24].

${ }^{145}$ To be found in Division 10 ('Circumstances involving external factors').
} 
'reasonably believes' that his or her actions were a reasonable response in the circumstances.

\section{Section 10.2 Duress}

(1) A person is not responsible for an offence [all Commonwealth offences including murder] if he or she carries out the conduct constituting the offence under duress.

(2) A person carries out conduct under duress if and only if he or she reasonably believes [this is not the reasonable person or ordinary person test but rather what the defendant might reasonably believe in all the circumstances $]^{146}$ that:

a threat [no limitation on the kind of threat that triggers the defence] ${ }^{147}$ has been made that will be carried out ${ }^{148}$ unless an offence is committed; and

there is no reasonable way that the threat can be rendered ineffective [objective test of necessity]; ${ }^{149}$ and

the conduct is a reasonable response to the threat [objective test of proportionality of response]. ${ }^{150}$

\footnotetext{
${ }^{146}$ Odgers, above n 25, 103 [10.2.150] citing Oblach v The Queen (2005) 65 NSWLR 75 [56][57] (Spigelman CJ) where the authority of Mason J in Viro $v$ The Queen (1978) 141 CLR 88 was considered to be 'helpful'.

${ }^{147}$ The implication from the lack of qualification of 'a threat' is that the threatener need not be physically present when the offence is carried out ( $R v$ Hurley and Murray [1967] VR 526), that the threat need not be carried out immediately but could be carried out after a short interval ( $R$ v Hudson and Taylor [1971] 2 QB 202), that the threat must not be too remote from the criminal conduct ( $R v$ Hudson and Taylor [1971] 2 QB 202) and that the threat need not be directed at the accused but can be indirect - for example it can be aimed at a third person ( $R$ v Hurley and Murray [1967] VR 526).

148 Bronitt and McSherry, above n 6, 322, suggest that 'it would seem that an honest and reasonable, but mistaken belief may form the basis for a defence of duress', citing $R v$ Graham [1982] 1 WLR 294, 300 (Lord Lane CJ).

149 'In all jurisdictions, there is a legal duty on the accused to escape from the person making threats should a reasonable opportunity to do so present itself': Bronitt and McSherry, above n 6, citing, inter alia, $R \vee$ Abusafiah (1991) 24 NSWLR 531.

${ }^{150}$ In Oblach $v$ The Queen (2005) 65 NSWLR 75 [55] Spigelman CJ said the following of the defence of duress in s 10.2 of the Criminal Code (Cth): 'Paragraphs 10.2(2)(b) and (c) each adopt the word "reasonable" to apply an objective test to the elements of necessity and proportionality of response.' Odgers, above n 25, 104 [10.2.210], has suggested that 'since this provision reflects the common law, it is likely that it will be "construed against the strong policy considerations in this area of the law": Morris $v$ The Queen [2006] WASCA 142 [154] (McClure J)'. Such policy considerations reflect the presumption that under ordinary circumstances criminal intimidation is reported to the police ( $R v$ Brown (1986) 43 SASR 33, 40 (King CJ)).
} 
The same approach can be taken to any one of the defences in Part 2.3 of the Criminal Code (Cth) to reinforce the theme of this paper that a copious body of case law sits behind such short sections in Codes. Indeed, the interpretation of a section may be further muddied if a well known common law test has been slightly altered, as in section 10.4(2), which deals with the subjective (conduct is necessary) and objective (reasonable response) tests for selfdefence. Section 10.4(2) dilutes the objective test by the use of the words 'the conduct is a reasonable response in the circumstances as he or she ['reasonably' has been omitted] perceives them'. ${ }^{151}$ It might be better and more accurate to include a statement in a Criminal Code that expressly recognises the importation of the common law, such as the one to be found in section 5(2) of the Defamation Act 2006 (NT):

This Act does not affect the operation of the general law in relation to the tort of defamation except to the extent that this Act provides otherwise (whether expressly or by necessary implication).

This paper takes issue with Leader-Elliott's response to his own question of what happened to the common law of criminal responsibility in Chapter 2 Criminal Code (Cth). The learned author replied that

traces remain, secreted in the statutory interstices of Chapter $2 \ldots$ [T]here will be occasions when judicial recourse to common law principles will be unavoidable for want of guidance in the Code. ${ }^{152}$

However, with respect, in point of fact the writing ${ }^{153}$ of the common law is plainly showing on the palimpsest on which Chapter 2 of the Criminal Code (Cth) is superimposed. Chapter 2 resembles a cipher that requires a common law decoding book to make sense of its provisions.

A rather poignant example of the statute law of another jurisdiction (rather than the common law) seeping in and filling up the gaps can be seen in the interpretation of section 8 of the Criminal Codes for Queensland and Western Australia, which deals with offences committed in prosecution of a common

151 (emphasis added). Compare s 29(2)(b) Criminal Code (NT) which follows the common law objective test of a reasonable response as the person reasonably perceives the circumstances with the Model Criminal Code importation in s 43BD(2)(b) Criminal Code (NT) which allows the perception to be subjective by omitting 'reasonably'.

${ }^{152}$ Leader-Elliott, above n 85, 215.

${ }^{153}$ A palimpsest is a parchment manuscript page from a scroll or book that has been scraped off and used again. Windeyer J in Vallance $v$ The Queen (1961) 108 CLR 56, 76, famously commented that 'we cannot interpret its general provisions [Criminal Code (Tas)] concerning such basic principles [of criminal responsibility] as if they were written on a tabula rasa. Rather is ch.iv of the Code written on a palimpsest, with all the old writing still discernible behind'. 
purpose. Queensland has no sub-section on withdrawal from the common purpose. In this respect it is unlike Western Australia, where withdrawal is covered in section 8(2) and allows the person to avoid criminal responsibility if, after having withdrawn, he or she 'took all reasonable steps to prevent the commission of the offence'. ${ }^{154}$ The response of the Queensland judiciary has been to 'import' the reasonable steps test from Western Australia into section 8 of the Criminal Code (Qld), which is silent on withdrawal, rather than the more stringent common law test of the defendant needing to eliminate his or her conduct as a cause of the ultimate offence. ${ }^{155}$

Earlier in this section of the paper mention was made of the partial defences to murder of diminished responsibility and provocation, neither of which is available under the Criminal Code (Cth) but both of which are available under the Criminal Code (Qld) ${ }^{156}$ and the Criminal Code (NT). ${ }^{157}$ To illustrate the theme of this paper - that the common law infuses short sections in Codes section 304 of the Criminal Code (Qld) will be contrasted with a proposed amended section 158 of the Criminal Code (NT). While the former deals with provocation and cannot be properly read without knowledge of the common law, the latterspells out the meaning of the section and the tests to be applied in some detail. Section 304 reads:

When a person who unlawfully kills another under circumstances which, but for the provision of this section, would constitute murder, does the act which causes death in the heat of passion caused by sudden provocation, and before there is time for his passion to cool, he is guilty of manslaughter only.

Kenny points out that in Queensland 'in the absence of a statutory definition of provocation for murder, reliance is placed upon the principles pertaining to provocation as they develop at common law'. ${ }^{158}$ The section hides both a subjective and objective test. The 'heat of passion' requirement introduces a subjective test whereby all the surrounding circumstances may be taken into account such as the personal characteristics of the defendant. ${ }^{159}$ But this test based on loss of self-control is constrained by an objective requirement that

\footnotetext{
${ }^{154}$ See s 8(2)(c) Criminal Code (WA).

${ }^{155}$ See, eg, White $v$ Ridley (1978) 140 CLR 342, 350 (Gibbs J) and $R v$ Menitti [1985] 1 Qd R 520, 528 (Thomas J).

${ }^{156}$ See s 304A for diminished responsibility and s 304 for provocation.

${ }^{157}$ See s 159 for diminished responsibility and s 158 for provocation. Both defences are also available in New South Wales (s 23 and s 23A Crimes Act 1900) and the Australian Capital Territory (s 13 and s 14 Crimes Act 1900).

${ }^{158}$ Kenny, above n 128, 250 [12.52] citing High Court authority in Kaporonovski v The Queen (1973) 133 CLR 209.

${ }^{159}$ Parker v The Queen (1964) 111 CLR 610, 628.
} 
the provocation must have been sufficient to be likely to deprive the ordinary person of the power of self-control and induce the act that caused the death. ${ }^{160}$ This is a classic example of the common law devising a two-step test invisible to the ordinary lay reader of the Code.

By contrast, and in keeping with Bentham's call for 'no blank spaces' in a criminal code, the present author has rewritten section 158 of the Criminal Code (NT) below to clarify how the partial defence to murder of provocation is designed to operate.

158 Trial for murder - partial defence of provocation

(1) A person (the defendant) who would, apart from this section, be guilty of murder must not be convicted of murder if the defence of provocation applies.

(2) The defence of provocation applies if the conduct of the deceased was such as could have induced an ordinary person to have so far lost selfcontrol as to have formed an intent to kill or cause serious harm to the deceased.

(3) Loss of self-control is defined as meaning a sudden and temporary loss of self-control, rendering the defendant so subject to passion as to make him or her for the moment not master of his or her mind. ${ }^{161}$ The loss of selfcontrol due to resentment, grievance or revenge is specifically excluded. ${ }^{162}$

(4) The defendant must not have incited the provocation. ${ }^{163}$

(5) Grossly insulting words or gestures towards or affecting the defendant are excluded from conduct of a kind that induces the defendant's loss of self-control.

(6) A defence of provocation may only arise if the conduct of the deceased occurred immediately before the conduct causing death and not at an earlier time. $^{164}$

\footnotetext{
${ }^{160}$ Stingel $v$ The Queen (1990) 171 CLR 312, 325.

161 Taken from Devlin J's classic definition in $R v$ Duffy [1949] 1 All ER 932. See also Tindal CJ in $R v$ Hayward (1833) 6 C \& P 157, 159 who described the provocation defence as applying to an accused who acted 'while smarting under a provocation so recent and so strong that the prisoner might not be considered at the moment the master of his own understanding'. 162 Van den Hoek $v$ The Queen (1986) 161 CLR 158.

${ }^{163}$ This has the effect of reintroducing the now repealed s 34(2)(a) of the Criminal Code (NT).

164 This subsection specifically ousts authority to the effect that the provocation should be considered in the light of the whole history of the relationship. See, eg, Moffa $v$ The Queen (1977) 138 CLR 601.
} 
(7) Conduct of the deceased consisting of a non-violent sexual advance or advances towards the defendant is not a sufficient basis for a defence of provocation.

(8) Conduct of the deceased consisting of the deceased's choice about a relationship with the defendant is not a sufficient basis for a defence of provocation. ${ }^{165}$

(9) For deciding whether the conduct causing death occurred under provocation, there is a rule of law that provocation is negatived if:

(a) there was no reasonable proportionality between the conduct causing death and the conduct of the deceased that induced the conduct causing death; or

(b) the conduct causing death did not occur suddenly.

(10) The burden of establishing a defence of provocation is a legal burden and lies on the defence. ${ }^{166}$

(11) A defendant who would, apart from this section, be liable to be convicted of murder must be convicted of manslaughter instead.

The above proposed section explicitly defines the nature of the partial defence. The policy decisions that narrow the defence to only the most serious of provocations, in relation to which the defendant bears the legal onus of proof on the balance of probabilities, are clearly stated. No recourse to second reading speeches is necessary.

In summary, when one casts an eye over this potpourri of defences, from claim of right and duress in the Criminal Code (Cth) to provocation in the Criminal Codes of Queensland and the Northern Territory, one sees that the golden thread of the common law runs through and links all these defences. Unlike Part 2.2 of the Criminal Code (Cth), which is a comprehensive statement of the elements of an offence, Part 2.3 ('Circumstances in which there is no criminal responsibility') draws far more heavily on the common law, both explicitly and implicitly.

\footnotetext{
165 The ordinary person does not respond to a relationship breakdown by killing his or her partner. 'Men who kill when affronted by their intimate partners are truly extraordinary': G Coss, 'The Defence of Provocation: An Acrimonious Divorce from Reality' (2006) 18(1) Current Issues in Criminal Justice 51, 53.

${ }^{166}$ Above n 79, 11. The Queensland Law Reform Commission recommended that s 304 of the Criminal Code (Qld) should be amended by adding a provision to the effect that the defendant bears the onus of proof of the partial defence of provocation on the balance of probabilities.
} 


\section{CONCLUSION}

This paper has contended that criminal codes in Australia are misnamed because they fail the fundamental test for a code of comprehensively stating the criminal law in one statute. In particular, they fail Bentham's test requiring 'no blank spaces' in a criminal code. In fairness, it has to be said that the Criminal Code (Cth), based as it is on the Model Criminal Code, achieves far greater success against this measure than any of the criminal codes in Australia that fall under the rubric of the Griffith Codes.

The Griffith Codes suffer the fatal flaw recognised by Dixon CJ in Vallance, namely that the central criminal responsibility section often has little or nothing to say about the elements of offences. This was problematic because the central provision of the Tasmanian Code (section 13) came 'ab extra', restraining the operation of what followed even though common sense dictated resolution outside of section 13 itself.

Whilst Part 2.2 of the Criminal Code (Cth) is a comprehensive statement of the elements of an offence, it has been suggested that even here two conclusions can be drawn from recent cases interpreting Chapter 2, such as $R$ $v$ Saengsai-Or and The Queen $v$ Wei Tang. The first is that judges have the same difficulties in interpreting Chapter 2 of the Criminal Code (Cth) as they have in interpreting any other Code or statute. Secondly, Dixon CJ's dicta in Vallance, that specific solutions to code provisions have be worked out judicially, are as valid today as when the Chief Justice wrote them in 1961.

This argument gathers strength when the focus turns to Part 2.3 ('Circumstances in which there is no criminal responsibility'), where the imprint of the common law is still discernible behind the Code sections - like the old writing on a palimpsest, to paraphrase Windeyer $\mathrm{J}$ in another evocative image from Vallance. Perhaps, in truth, Bentham's requirement of 'no blank spaces' in a Criminal Code is unattainable. In this case it would be more appropriate and fitting to explicitly recognise the operation of the common law except to the extent that the Code provides otherwise, rather than to trumpet (see 2.1 'Purpose') the assertion that Chapter 2 contains all the general principles of criminal responsibility that apply to any offence. This paper has provided a suggested template as to how defences in Part 2.3 could be more explicitly expressed. Such a template would either give greater credibility to section 2.1 ('Purpose') or underpin the recognition of the common law unless specifically excluded in the Code. The law has always been more concerned with substance than form, and a code does not necessarily qualify as a code simply by calling a body of statute law a code. 